Article

\title{
Impact of Capital Structure on Corporate Value-Review of Literature
}

\author{
Sylwia Kruk (i)
}

check for updates

Citation: Kruk, Sylwia. 2021. Impact of Capital Structure on Corporate Value-Review of Literature. Journal of Risk and Financial Management 14: 155. https://doi.org/10.3390/ jrfm14040155

Academic Editor: Renata Korsakienè

Received: 26 February 2021

Accepted: 29 March 2021

Published: 1 April 202

Publisher's Note: MDPI stays neutral with regard to jurisdictional claims in published maps and institutional affiliations.

Copyright: (C) 2021 by the author. Licensee MDPI, Basel, Switzerland This article is an open access article distributed under the terms and conditions of the Creative Commons Attribution (CC BY) license (https:// creativecommons.org/licenses/by/ $4.0 /)$.
Department of Economics and Organisation of Enterprises, Cracow University of Economics, Rakowicka 27, 31-510 Cracow, Poland; kruks@uek.krakow.pl

\begin{abstract}
The issue of capital structure in an enterprise is often described in the literature on the subject; however, theories are classified into various approaches, and their characteristics are often limited to selected theories. This work is an attempt at a synthetic presentation of the theory of capital structure. The aim of the article was to review and try to organise the most important theories of capital structure, paying attention to the influence of capital structure on the processes of creating value. The paper also highlights the most important theoretical works in this area. The study consists of two main parts. The first part indicates the diversity of defining the concepts of capital structure and indicates the approaches in classifying this structure. The second part characterises the theories of capital structure in the context of value creation. Based on the presented theories, it can be stated that there is no agreement as to whether and to what extent capital structure translates into the process of creating enterprise value. Therefore, it seems justified to conduct appropriate empirical research in this respect.
\end{abstract}

Keywords: capital structure; capital structure theories; capital structure decisions; financial management; external financing; corporate value; finance management

\section{Introduction}

There are a number of sources for financing business activity, both in the context of one's own and external financing. In the literature on the subject, there is no full agreement as to the definition of the concept of capital structure. Usually, attention is focused on the ratio of equity to debt in this context. Sometimes, it is understood as a liability structure, and another approach differentiates between the concepts of financing structure and capital structure. In this sense, capital structure includes equity and long-term liabilities and is part of the financing structure (which also includes current liabilities). The concept of enterprise value is also understood in various ways. In the theory of capital structure, it is assumed that this is the amount that a buyer is willing to pay in return for the expected cash flows; therefore, it is determined by the sum of the future discounted cash flows. In the context of the classification of the theory of capital structure, the most common division is into tax and non-tax theories, into static and dynamic theories, and from the perspective of the perfect and imperfect market. The study attempts to classify the perspective of a company's value.

The research that has been conducted since the middle of the last century (e.g., Durand 1952; Modigliani and Miller 1963; Miller 1977; Modigliani 1982; DeAngelo and Masulis 1980; Hand et al. 1982; Myers 1984) has led to the identification of many theories that are related to the structure of capital and its impact on the value of an enterprise. These theories are often very diverse and are often mutually exclusive. According to some theories, the value of an enterprise is not related to its capital structure; e.g., the net operating income theory (Durand 1952) and the Modigliani-Miller theory in an economy without taxes (Modigliani and Miller 1958). On the other hand, the structure of capital affects this value according to others; e.g., the net income theory, the compromise theory (Durand 1952), the Modigliani-Miller theory in an economy with taxes (Modigliani and Miller 1958), the 
Miller theory (Miller 1977), the DeAngelo and Masulis (1980) model, the static trade-off theory (Mursalim and Kusuma 2017); (Gajdka and Szymański 2019), the bankruptcy costs theory (Baxter 1967), the pecking order theory (Myers 1984), and the agency costs theory (Jensen and Meckling 1976).

This work is an attempt at a synthetic presentation of the theory of capital structure. The literature on the subject often points to the aforementioned issues; however, the theories are classified into various approaches, and their characteristics are often limited to selected approaches. The aim of thise study was to review and try to organise the most important theories that are related to the structure of capital together with an indication of the most important theoretical works. The work consists of two main parts. The first defines the concept of capital structure and presents the classification of capital structure theory. In the second, theories of capital structure are characterised in the context of creating enterprise value. Unfortunately, the presented concepts do not provide uniform unambiguous villages regarding the recommended capital structure from the perspective of the processes of creating enterprise value. Due to the limitations of the scope of work, the description is synthetic by definition.

\section{Materials and Methods}

The review of the literature was aimed at organising the theory of capital structure and identifying the theory of capital structure in the context of value-creation processes. There is no uniform nor synthetic presentation of the indicated problems in the literature on the subject. First, a review of the literature was made, which is of key importance from the point of view of the indicated issues. The data for this particular research paper was retrieved mainly from November 2020 through January 2021 from the Journals \& Books ScienceDirect collection and Jstor database. The search covered the entire content of each database with no time limits. The search was conducted using the terms "capital structure" and "company value". Keywords were observed in the titles, abstracts and author's keywords.

\section{Results}

In a short period of time, enterprises are oriented towards maximising the operating result and demonstrating the highest possible operational efficiency. However, the goal of the action is to maximise value in the long run (Jonek-Kowalska 2020). The value of an enterprise can be understood in various ways; e.g., as book value, liquidation, replacement, or economic value. In the theory of finance, an important role is played by the concept of economic value, which is understood as the amount that a buyer is willing to pay for an enterprise in return for the expected cash flows; therefore, the value of the enterprise can be determined as the sum of the expected cash flows-Formula (1). If the prices of the capital assets reflect all of the available information about them, then the capital market is efficient. Then, their market value corresponds to the economic value, which is the present value of the future cash flows that can be obtained through the use of these assets (Duliniec 2001).

$$
V=\sum_{t=1}^{\infty} C F_{t} \cdot \frac{1}{(1+k)^{t}}
$$

where:

t-time;

$C F_{t}$ - cash flow during t-period of forecast;

$k$-discount rate equal to cost of capital.

As noted by Sierpińska and Jachna (2017), the capital structure that enables a minimisation of the weighted average cost of capital leads to a maximisation of a company's value, as the expected cash flows are discounted at a lower discount rate. The concept of capital structure is sometimes understood in various ways; there is no consensus as to its definition. S.C. Myers (2001) noted that most research in the area of capital structure has focused on the debt-to-equity ratio, which is reflected on the right side of a balance 
sheet. Orlova et al. (2020) pinpointed that capital structure is usually presented in the context of a choice between debt and equity. K. Ardalan (2017) defined capital structure as a mixture of debt and equity. On the other hand, M. Jerzemowska (2018) and Janasz (2010) defined capital structure as the ratio of equity to foreign capital. A. Ripamonti (2020) indicated that capital structure is represented by the average debt-equity ratio of companies, and capital structure is the optimal combination of equity and long-term debt according to Khémiri and Noubbigh (2018). A. Michalak pointed out that, under a different approach, it is necessary to distinguish between the concepts of financing structure and capital structure. In this context, the financing structure indicates how an enterprise is financed and is, therefore, reflected in the liabilities of the balance sheet. On the other hand, the structure of capital is understood as equity from the issue of shares, privileged capital, and long-term debt. In this sense, the capital structure is part of the financing structure. Thus, the financing structure includes equity and long-term external capital as well as current liabilities. Thus, the capital structure corresponds to the structure of the liabilities less the current liabilities. The fact that the current liabilities are excluded from the consideration is a result of the fact that their value fluctuates; therefore, the capital structure is determined by equity and long-term liabilities in the longer term. A different approach to the capital structure takes equity, long-term liabilities, and interest-bearing short-term liabilities into account. This results from the assumption that the entities that invest capital in an enterprise are oriented towards obtaining income that they can obtain from this account (Michalak 2015a). If it is assumed that, if equity includes equity and interest-bearing debt, it will represent a value that is lower than the balance sheet total. This approach is consistent with the understanding of the debt-equity relationship of an enterprise by F. Mogigliani and M. Miller, who believe that the most important feature of debt as an element of capital structure is the payment of interest (Michalak 2015b).

The issues of capital structure or financing structure are analysed in various approaches-Table 1. The presented measures can be calculated with the use of book values or market values. The assumption of market values may cause measurement difficulties. On the other hand, S. Myers (1977) observed that the adoption of book values better takes into account the fact that tangible assets provide a better security for a loan than intangible assets and cause intangible assets to show growth opportunities.

Table 1. Concepts of capital structure.

\begin{tabular}{|c|c|}
\hline $\begin{array}{l}\text { Perspective of Analysing } \\
\text { Capital Structure }\end{array}$ & Meters \\
\hline $\begin{array}{l}\text { Capital structure is identified with structure of } \\
\text { liabilities of balance sheet; it is also called } \\
\text { structure of financing sources used in financing } \\
\text { company's operations (R.W. Masulis) }\end{array}$ & $\begin{array}{l}\text { capital multiplier (CM) (ratio of total } \\
\text { assets to equity); } \\
\text { debt ratio (ratio of liabilities and } \\
\text { provisions for liabilities to total assets); } \\
\text { short-term debt ratio (ratio of short-term } \\
\text { liabilities to total assets); } \\
\text { long-term debt ratio (ratio of long-term } \\
\text { liabilities to total assets). }\end{array}$ \\
\hline $\begin{array}{c}\text { Capital structure is relationship between equity } \\
\text { and borrowed capital with repayment period } \\
\text { of more than one year }\end{array}$ & $\begin{array}{l}\text { ratio expressing relationship of long-term } \\
\text { liabilities to equity. }\end{array}$ \\
\hline $\begin{array}{l}\text { Capital structure expresses combination of } \\
\text { debt and equity securities issued by company }\end{array}$ & $\begin{array}{l}\text { - } \quad \text { debt securities-to-equity ratio; } \\
\text { ratios expressing relationship of value of } \\
\text { individual debt securities issued by } \\
\text { enterprise to equity; } \\
\text { ratio showing relationship of debt from } \\
\text { bonds issued to market capitalisation } \\
\text { (value of securities is calculated as } \\
\text { product of number of shares and current } \\
\text { stock exchange price). }\end{array}$ \\
\hline
\end{tabular}


Table 1. Cont.

\begin{tabular}{cll}
\hline $\begin{array}{c}\text { Perspective of Analysing } \\
\text { Capital Structure }\end{array}$ & \multicolumn{1}{c}{ Meters } \\
\hline $\begin{array}{c}\text { Capital structure reflects equity and long- and } \\
\text { short-term liabilities, excluding liabilities to } \\
\text { suppliers, tax liabilities, and remuneration }\end{array}$ & $\bullet \quad \begin{array}{l}\text { ratio showing relationship of } \\
\text { interest-bearing long- and short-term } \\
\text { liabilities to equity; } \\
\text { interest-bearing debt ratio (ratio of } \\
\text { interest-bearing liabilities to total assets). }\end{array}$ \\
\hline Source: Own work based on (Gostkowska-Drzewicka 2014; Pomykalska and Pomykalski 2017; Gajdka 2002).
\end{tabular}

Basically, the division of the capital structure theory may concern the following (Guzanek and Trojak 2012):

- inference related to particular theories-and therefore whether the debt affects the market value of an enterprise;

- accounting for taxation-tax and non-tax theories;

- assumptions about the functioning of the market.

In the literature on the subject, various approaches to the classification of the capital structure theory can be found with varying degrees of detail. Usually, the main criteria are those factors that influence this structure. The most general division is made into tax and non-tax theories. Another approach to the division of the theory of capital structure takes the criterion of the state within which the structure is analysed into account. In this context, static and dynamic theories are distinguished. Static theories are based on the assumption that a certain amount of capital is necessary to finance a company's operations; the optimal capital structure is sought within them. This group includes such models as the MM model of F. Modigliani and M. Miller, the traditional approach represented by J.B. Warner, H. DeAngelo., L. Dodd, D. Durand, R.W. Masulis, and B. Graham, and the trade-off model represented by J.B. Warner and H. DeAngelo (Jaros and Bartosova 2015), for example. According to dynamic theories, the amount of capital changes since each company is a unique organism; the order in which it should be obtained becomes a problem. The indicated changes in capital are usually related to its increase as a result of making invest-ment decisions. Depending on the capital that is employed, its optimal structure will be different; therefore, we cannot talk about the target debt/equity ratio (Gajdka 2002), as this is in the case of static theories. This group of theories is represented by S. Myers (the pecking order theory), which is based on research that was conducted by G. Donaldson (Jaros and Bartosova 2015).

One approach is to consider the capital structure theory from the perspective of a perfectly competitive and imperfect market-Table 2 . The theories of a perfect market are logical and coherent, but the assumptions made about market perfection mean that they do not fully reflect economic reality.

Table 2. Classification of capital structure theory from the perspective of perfectly competitive and imperfect market.

\begin{tabular}{cll}
\hline Specification & \multicolumn{1}{c}{ Theories } \\
\hline & $\bullet$ & net income theory \\
Theories of perfect market & - net operation income theory \\
& - Mompromise theory \\
& - Miller theory \\
\hline
\end{tabular}


Table 2. Cont.

\begin{tabular}{lll}
\hline \multicolumn{2}{c}{ Specification } & \multicolumn{1}{c}{ Theories } \\
\hline - & static trade-off theory \\
Theories of imperfect market & bankruptcy costs theory \\
& - $\quad$ information asymmetry theory: \\
& - signalling theory \\
& - thency costs theory \\
& & theory of competition to take control of company \\
& factors of production
\end{tabular}

Source: Own work based by (Guzanek and Trojak 2012; Gajdka 2002).

A. Miglo (2011) and A. Dulinec (2015) pointed out that the main theories of capital structure are as follows:

- $\quad$ the trade-off theory;

- the pecking order theory;

- the signaling theory;

- the market timing theory.

On the other hand, L. Pacheco (2016) and Prędkiewicz and Prędkiewicz (2014) listed the following in the theories that determine the determinants that influence the choice and proportions of equity and foreign capital: the static trade-off theory, the agency cost theory, and the pecking order theory. In turn, J. Gajdka (2002) pointed us to the following theories of capital structure:

- initial theories:

- primary theories (the net income theory, the net operation income theory, the compromise theory),

the Modigliani-Miller theory for an economy without taxes;

- tax theories:

the Miller-Modigliani model for an economy with taxes,

the Miller model,

the DeAngelo Masulis model,

the Modigliani model;

- the bankruptcy costs theory;

- the agency costs theory;

- the information asymmetry theory:

the pecking order theory (the Myers-Mayluf model, the Myers model);

the signailing theory (the Ross model).

In the context of the problem of capital structure, an optimal relationship between equity and external capital is sought at which the value of an enterprise is maximised; therefore, the following questions can be asked (Gajdka 2002):

- does the capital structure affect the market value of a company?

- is there an optimal capital structure (i.e., one where the market value of a company is the highest and the cost of the capital is the lowest) and, if so, which factors determine it?

Taking the variety of financial instruments into account, it can be assumed that the possibilities in the area of shaping capital structure are unlimited, as this relationship may take values from zero to infinity. Determining whether there is an optimal capital structure would mean that it is possible to maximise the value for shareholders by appropriately shaping a company's capital structure. Thus, its value would be influenced not only by its investment decisions but also by its financial decisions. 
In the literature on the subject, two approaches can be distinguished in the context of the impact of capital structure on the value of an enterprise-Table 3. According to the first approach, capital structure does not affect the value of an enterprise. Under the second approach, however, it is assumed that there is a particular capital structure at which the value of an enterprise is maximised.

Table 3. Classification of capital structure theories from the perspective of its impact on corporate value.

\begin{tabular}{|c|c|}
\hline Specification & Theories \\
\hline $\begin{array}{l}\text { Theories according to which capital structure } \\
\text { does not affect value of enterprise }\end{array}$ & $\begin{array}{l}\text { - } \quad \text { theory of operating profit } \\
\text { Modigliani-Miller theory in economy } \\
\text { without taxes }\end{array}$ \\
\hline $\begin{array}{l}\text { Theories according to which capital structure } \\
\text { affects value of enterprise }\end{array}$ & $\begin{array}{l}\text { - } \quad \text { net income theory } \\
\text { - } \quad \text { Modigliani-Miller theory in economy } \\
\text { - } \quad \text { Mith taxes } \\
\text { - } \quad \text { Modigliani model } \\
\text { - } \quad \text { static trade-off theory } \\
\text { - } \quad \text { DeAngelo-Masulis model } \\
\text { - } \quad \text { agency cost theory } \\
\text { - } \quad \text { pecking order theory } \\
\text { - } \quad \text { theory of competition to take control of } \\
\text { - } \quad \text { theory of situation on market of products } \\
\text { and factors of production }\end{array}$ \\
\hline
\end{tabular}

Source: Own work.

\section{Discussion}

The problem of the theory of capital structure was first taken up by D. Durand, who made an attempt in 1952 to explain the dependencies between the structure of capital and the cost of its acquisition; he also pinpointed out that basic economic theories require revision (Durand 1952). On the other hand, the Modigliani-Miller model is considered to be the source of the development of the theory of corporate finance. In the abovementioned work, D. Durand gathered the available information and presented his research proposals. These considerations were later referred to as the original theories of capital structure. He believed that the correct valuation method was the income method that was based on discounting, as he assumed that "the businessman tries to maximise the discounted value of his future income" (Durand 1952) and that the issue of estimating the cost of capital is inherently related to the aspect of measuring the value of an enterprise. Therefore, based on three methodological approaches that are used in the valuation of companies, he focused on the net profit, operating profit and compromise approaches (now considered traditional) and also drew attention to the relationship between capital structure, its cost, and a company's value.

In the area of the net operating income theory, it is assumed that the value of an enterprise depends solely on its level of operating profit. As investors expect a higher risk premium as debt increases, the cost of equity increases. The cost of debt capital does not change, nor does the weighted average cost of capital, as changes in the debt level cause adequate changes in the cost of equity. Within the framework of the indicated theory, the value of an enterprise is not related to the structure of its financing. According to D. Durand, the indicated dependencies only exist when a company has a reasonable amount of debt. Excessive indebtedness poses a risk of bankruptcy and reduces the value of an enterprise, as investors will want to pay less for its stocks and bonds (Durand 1952). 
The net income theory assumes that the value of a company is proportionate to its share of debt in its capital structure (Kedzior et al. 2020); the costs of capital do not change regardless of the structure of the financing sources. Moreover, it is assumed that foreign capital is usually characterised by a lower cost of acquisition than equity is. As debt increases, the weighted average cost of capital is, thus, reduced, and the value of an enterprise is maximised (Durand 1952). Both the net operating income theory and the net income theory apply to a situation where there is no income tax in a company's economy.

The compromise theory combines the theory of operating profit and the theory of net profit in a way. According to it, the owner(s) of a company accept debt to a certain level and do not expect an additional risk premium. Thus, the weighted average cost of capital will decrease and the company's market value will increase as long as the share of debt does not reach an acceptable limit as it grows. Once the abovementioned acceptable level is exceeded, however, the donors of both the equity and foreign capital will expect an additional higher risk premium. Thus, the weighted average cost of capital will increase, and as a result, the market value of the enterprise will decrease (Durand 1952).

The Modigliani-Miller theory was presented in a work that was prepared by Franco Modigliani and Merton H. Miller (Modigliani and Miller 1958) and is one of the most frequently mentioned theories in the litereture that are related to the structure of capital. Harris and Raviv (1991) pointed out that the modern theory of capital structure was initiated with the indicated article. F. Mogiliani and M.H. Miller presented the problem of the cost of capital and its structure in two planes in an economy without taxes and in an economy with taxes on corporate profits. In the first case, the value of an enterprise and the weighted average cost of capital do not depend on the capital structure (Modigliani and Miller 1958), as the increase in the share of cheaper foreign capital is accompanied by an increase in financial risk. This translates into an increase in the rate of return that is expected by the shareholders (Czerwonka 2017). In the second variant, the value of an undebted enterprise corresponds to the expected amount after tax capitalised by using an interest rate that is appropriate to an enterprise of a given risk class. On the other hand, the value of an indebted entity corresponds to the value of the non-indebted entity increased by the value of the tax savings depending on the tax rate and the company's debt (Sierpinska and Jachna 2007). Growing shareholder requirements cover the financial benefits of the growing portion of the debt so that the average cost of the capital will remain the same for any capital structure. Thus, the expected rate of return on the equity of a company with debt increases directly to the debt-to-equity ratio that is expressed by market value. The rate of this growth depends on the difference between the expected rate of return on the total capital and the rate of return on the debt (interest rate) (Jaros and Bartosova 2015). In subsequent papers, the autors noticed that growing debt causes the average cost of capital to decline under the influence of the interest shield. The return on capital and the market value also increase; therefore, a company should increase part of its debt while taking the capital structure into account (Jaros and Bartosova 2015). This does not mean that the company must maximise the amount of their debt at any price without taking other relevant facts into account. The same authors encouraged financial managers to not strive for maximum debt because, in some circumstances, other forms of financing may be cheaper. They considered the impact of personal income tax, increased creditor requirements, and other operating costs that cannot be captured in a static balanced model (Jaros and Bartosova 2015). In the model that assumes the existence of tax on income, F. Modigliani and M.H. Miller originally made a mistake. They detailed and corrected this in 1963 (Modigliani and Miller 1963).

Miller's theory was presented in his 1977 work entitled "Debt and Taxes" and is a kind of a modification of the Modigliani-Miller theory. In addition to taxes on profits, it also includes personal taxes on stocks and bonds. According to the presented model, the value of an enterprise with increasing debt may increase if its interest payments can be deducted from its income tax (Miller 1977). Additionally, the value of the enterprise is independent of its capital structure under equilibrium conditions (Miller 1977), as the 
interest rate assumes such a level that the capital structure will not affect the value of the enterprise (Gajdka 2002).

The Modigliani model is a development of the Modigliani-Miller model and was presented by F. Modigliani in 1982. He tried to explain that enterprises do not strive to maximise their share of debt in their capital structures, as debt is important as long as it serves as a protection mechanism against income taxes (Modigliani 1982). In his research, he indicated that the value of an enterprise depends on the dividend policy, financial policy, the risk of the generated cash flow, the covariance between the cash flow of various companies, and the consequences of liabilities and inflation (Gajdka 2002).

DeAngelo and Masulis (1980) examined the impact of tax shields that are generated by factors other than the repayment of interest on debt (for example, through a tax shield that resultis from non-cash payments; e.g., related to depreciation or investment tax breaks), which may translate into a reduction of the tax base to zero. They showed that there is a nonzero use of debt by companies that maximises the value of a company without incurring bankruptcy or agency costs (Ardalan 2017). DeAngelo and Masulis (1980) showed that it is possible to find an optimal capital structure for a company.

After the publications of F. Modigliani and M.H. Miller (Modigliani and Miller 1958; Modigliani and Miller 1963), a discussion arose on the basis of which the static trade-off theory (Yıldırım and Çelik 2020; Dabkowska 2016) was born. According to the indicated theory, a company should maintain solid investment plans and assets (Mursalim and Kusuma 2017). Each company has an optimal capital structure (Bilgin and Dinc 2019); the optimal capital structure is when the value of an enterprise is maximised (Gajdka and Szymański 2019). A company's capital structure is the result of a compromise between the tax advantage on its debt and its expected bankruptcy costs. An optimal capital structure could be described as a ratio of leverage where the marginal tax benefit of the debt equals the marginal cost of the bancruptcy (Bilgin and Dinc 2019). Companies will try to maximise the optimal financial leverage to maximise shareholder wealth (Orlova et al. 2020). T. Nguyen, M. Bai, Y. Hou, and M. Vu noted that, according to the trade-off theory, any deviation of the financial leverage from the optimal capital structure may result in a reduction in a company's value (Nguyen et al. 2021). However, this theory does not seem to explain those situations in which debt is completely absent (Miglo 2020). The existence of a tax shield increases the market value of the enterprise along with an increase in debt, because the financial costs reduce the tax base (Gajdka and Szymański 2019). J. Błach (2009) noted that, in the extended theory of substitution, agency costs are also taken into account.

The risk of bankruptcy is related to the occurrence of a number of costs of direct and indirect natures. The first group includes those costs that are related to disputes between a company's creditors (which extend the liquidation process of the assets) and its costs that are related to their sale, administrative expenses, and legal services. Indirect costs include lowering costs (resulting in lowering the quality of a company's products), selling assets at a lower price (in order to improve financial liquidity, but also the refusal by contractors to grant a trade credit), or increasing the interest on loans due to the increased risks (of enterprises). Indirect costs increase with increasing debt; thus, an enterprise should increase its debt only when the benefits of leverage increase faster than the costs of bankruptcy as the market value of the enterprise increases. If the costs of bankruptcy exceed the benefits of increasing debt, the increase in debt will reduce the value of the enterprise. Therefore, there is a certain optimal level of debt in the area of the indicated theory at which the value of the enterprise is maximised. N.D. Baxter noted that excessive leverage translates into an increase in the cost of capital. The presence of an income tax suggests that the presence of leverage is conducive to lowering the cost of the capital of an enterprise; however, the risk of bankruptcy prevents this phenomenon (Baxter 1967). Haugen and Senbet (1978) also indicated that, in a perfect market, the costs of the bankruptcy of a non-profitable enterprise are not related to its capital structure.

The considerations of the theory of agency costs were first described by Jensen and Meckling (1976). A number of conflicts of interest can arise within an agency's relationship. 
There are two basic groups: conflicts between a company's management board and its shareholders, and conflicts between its shareholders and its creditors. The management of a company (agents) does not always make decisions in accordance with the interests of its shareholders (principals). In small enterprises, this takes the form of a conflict between internal and external capital donors and not between owners and managers (nor between managers and donors of foreign capital) (Hand et al. 1982). According to the theory of agency costs, monitoring mechanisms can improve the relationship between the management process and the interests of shareholders, as well as mitigate any opportunistic behaviour resulting from a conflict of interest (Kazemian and Sanusi 2015). In the context of agency costs, debt financing reduces the need to gain capital from shareholders, and a high level of indebtedness translates into an improvement in enterprise management procedures (Prędkiewicz and Prędkiewicz 2014); otherwise, the management board will lose control over the company. Therefore, the debt must be repaid; otherwise, the company will go bankrupt. This translates into improved business management procedures, as managers will be more cautious about spending cash (Vo 2021). According to the agency costs theory, an optimal capital structure that maximises the value of a company can be achieved by minimising the conflicts of interest between the stakeholders (Shoaib and Siddiqui 2020). As the share of debt increases, agency costs change ambiguously. On the one hand, the increase in indebtedness lowers the agency costs that are related to the conflict between the shareholders and the management board; on the other hand, it increases the agency costs that are the result of conflict between the shareholders and the creditors (Gajdka 2002).

B. Włoszczowski (2001) noted that, after taking the costs of bankruptcy and the agency costs into account, the Modigliani-Miller model transforms into a model of a balanced choice of capital structure in an economy with taxes. The optimal capital structure is related to the necessity of choice between the benefits and the costs of financing with foreign capital. The benefits of using financial leverage can be approximated, but the costs that are associated with financial difficulties and agency costs are subjective.

According to the information asymmetry theory, individual interest groups possess different information about economic entities and their transactions. Information asymmetry can lead to moral hazard, as those parties with an information advantage may use it to obtain greater benefits at the expense of those parties that are less informed. As part of the information asymmetry, there are a number of phenomena that may affect the relationship between the amount of debt and the value of an enterprise. Within the framework of the indicated theory, the theory of the hierarchy of financing sources and the signalling theory can be distinguished.

According to the pecking order theory of financing sources, it is not possible to determine the optimal capital structure over the long term, but it is possible to decide on a rational order of funds that are obtained for a new investment projects (Gajdka and Szymański 2019). Enterprises reduce debt financing along with the increase in profitability (Gajdka and Szymański 2019). S.C. Myers (1984) noted that enterprises prefer internal sources of financing that take the cost of resourses into account (Anton and Afloarei Nucu 2021), this was confirmed by the research carried out by Duran and Stephen (2020), for example, which was conducted for five countries in Latin America (Argentina, Brazil, Chile, Mexico, and Peru). If the funds that are obtained from these sources as well as those from external financing sources other than capital sources are insufficient, external sources of debt financing are used (Mokhova and Zinecker 2014), with enterprises preferring lowrisk debt (Yıldırım and Çelik 2020). Therefore, companies will use the retained profits whenever possible (Vo 2021). On the other hand, the least frequently chosen form of financing is issuing shares, which may lead to a dilution of equity and, as a consequence, a decrease in the return on equity ratios and a decline in a company's listing on the stock exchange (Duliniec 2007). Under this model, more-profitable companies should have lower leverages. If their investments are not solely financed by internal capital, companies with high investments and growth capacities will show high leverages. In a more complex version of this model, companies with high investments and growth potentials will have 
low leverage due to the current and future financing costs. Additionally, Myers (1984) anticipated that leverage decreases with higher levels of free cash flow (Aggarwal and Aung Kyaw 2010). Anton and Afloarei Nucu (2021) noticed that the profitalibilty of a company is negatively associated with its debt. A. Ullah et al. (2020) noted that the debt ratio is negatively correlated with size of a company, which was comfirmed in a study that was carried out in the textile sector of Pakistan.

S.C. Myers introduced the concept of a modified hierarchy theory; according to this, the selection of financing sources is influenced not only by the asymmetry of information but also by the costs of financial difficulties. According to it, the preferred sequence of financing sources does not change, but a company should not exceed a certain debt limit beyond which increased costs of financial difficulties will occur (Kubiak 2015).

According to the signaling theory, entities that are more closely related to an enterprise have a greater amount of information about future money flows at their disposal than other market participants. If managers' benefits are contingent on stock prices, they will be willing to send signals to the market that enable them to benefit from these benefits. It has been proven that entities with a smaller share of tangible fixed assets are characterised by a higher asymmetry of information, as they tend to underestimate investment projects more often (Jakubczyk and Lewandowska 2014).

In the literature on the subject, attention is also paid to the financial life cycle theory, where it is assumed that the life cycle influences the preferences regarding the structure of capital (Butzbach and Sarno 2019). In relation to younger and smaller enterprises, a greater asymmetry of information is shown, which affects the increase in the cost of capital (Kedzior et al. 2020). This theory points to a non-linear relationship between financial leverage and the age of an enterprise. At the beginning of a company's existence, the demand for external sources of financing is greater; however, as investment opportunities later decrease, enterprises are able to accumulate more funds to finance their activities (Butzbach and Sarno 2019).

The beginnings of the theory of competition to take control of a company can be traced back to the second half of the 1980s in connection with the processes of the mergers and acquisitions of companies. J. Gajdka (2002) noted that the problem of analysis is the market value of the right to control an enterprise, as equity instruments are related to a voting right, and debt instruments do not grant it. This problem was first characterised by M. Harris and A. Raviv, who identified four categories of capital structure determinants: mitigating conflicts among stakeholders, providing private information to capital markets or mitigating the negative effects of selection, influencing the nature of products or competition in the product market, and influencing the results of corporate competitions (Harris and Raviv 1991). In this context, the relationships among shareholders who want to take control of a company and those who do not want to take control are analysed. These relationships and the decisions made within them affect whether a company is taken over by a group that is competitive with the management board. The share of managers depends on the capital structure, and this structure affects the probability of a takeover, the share price, and the value of the company (Gajdka 2002).

It is assumed that the works that are related to the theory of the situation on the market of products and production factors were initiated by J. Brander and T. Lewis and by V. Maksimovic. In this context, the relationships between the characteristics of an industry or a company's environment and its capital structure are examined. In this area, two approaches are distinguished, which are focused on searching for premises that enable the determination of the capital structure (Gajdka 2002). In the first, the relationship between a company's financing policy and its strategy on the product market is examined; therefore, the financial structure will affect the behaviour of the sales market. In addition, enterprises will be able to predict the consequences of their financial decisions, so the conditions on the sales market will affect these financial decisions (Brander and Lewis 1986). The second subject of interest is the characteristics of the product and the type of production factors that are necessary for the functioning of an enterprise (Gajdka 2002). 
Finally, it is worth paying attention to the market timing theory, which does not define the optimal capital structure but rather points out that certain conditions of the capital market and macroeconomic conditions that may affect the capital structure of the listed companies (Serghiescu and Văidean 2014). Gan et al. (2021) showed that, in the event of macroeconomic risk, the speed of adapting the capital structure becomes much slower and enterprises adjust their debt faster under good macroeconomic conditions.

\section{Conclusions}

Running a business requires one to have certain property resources; the scope and size of these depend on the type of business that one has undertaken. However, ensuring the necessary property needs depends on having access to a sufficient amount of capital. The basic issues mentioned in the context of the theory of capital structure include the cost of capital and the value of an enterprise. Therefore, a question arises about whether one can influence the change of the cost of capital and the value of a company by changing the capital structure. The presented theoretical concepts of capital structure do not provide direct conclusions that clearly define the premises for making decisions in the context of shaping capital structure. There is also no agreement as to whether and to what extent capital structure translates into the processes of creating enterprise value. Therefore, it seems justified to conduct appropriate empirical research in this respect. Additionally, it should be noted that the functioning of enterprises in a changing environment results in the creation of new instruments, which creates the need to search for new theoretical solutions.

Funding: This research was funded with a subsidy for research granted to Cracow University of Economics: 77/ZZE/2020/POT.

Institutional Review Board Statement: Not applicable.

Informed Consent Statement: Not applicable.

Data Availability Statement: No new data were created or analyzed in this study. Data sharing is not applicable to this article.

Conflicts of Interest: The author declares no conflict of interest. The funders had no role in the design of the study; in the collection, analyses, or interpretation of data; in the writing of the manuscript, or in the decision to publish the results.

\section{References}

Aggarwal, Raj, and NyoNyo Aung Kyaw. 2010. Capital structure, dividend policy, and multnationality: Theory versus empirical. International Review of Financial Analysis 19: 140-50. [CrossRef]

Anton, Sorin Gabriel, and Anca Elena Afloarei Nucu. 2021. The Impact of Working Capital Management on Firm Profitability: Empirical Evidence from the Polish Listed Firms. Journal of Risk Financial Management 14: 9. [CrossRef]

Ardalan, Kavous. 2017. Capital structure theory: Reconsidered. Research in International Business and Finance 39: 696-710. [CrossRef]

Baxter, Nevins D. 1967. Leverage, Risk of Ruin and The Cost of Capital. Journal of Finance 22: 395-403. [CrossRef]

Bilgin, Rumeysa, and Yusuf Dinc. 2019. Factoring as a determinand of capital structure for large firms: Theoretical and empirical analysis. Borsa Instanbul Review 19: 273-381. [CrossRef]

Błach, Joanna. 2009. Ewolucja teorii struktury kapitału. Finanse. Czasopismo Komitetu Nauk o Finansach PAN 1: 87-106.

Brander, James A., and Tracy R. Lewis. 1986. Oligopoly and Financial Structure: The Limited Liability Effect. The American Economic Review 76: 956-70.

Butzbach, Olivier, and Domenico Sarno. 2019. To What Extent Do Regional Effects Influence Firms. International Journal of Financial Studies 7: 3. [CrossRef]

Czerwonka, Leszek. 2017. Struktura kapitału polskich spółek w świetle wybranych teorii. Contemporary Economy. Electronic Scientific Journal 8: 51-63.

Dąbkowska, Magdalena. 2016. Struktura kapitałowa spółek z sektora MSP na rynku NewConnect w latach 2010-2013. Finanse, Rynki Finansowe, Ubezpieczenia 4: 85-93. [CrossRef]

DeAngelo, Harry, and Ronald W. Masulis. 1980. Optimal Capital Structure Under Corporate and Pesonal Taxation. Journal of Financial Economics 8: 3-29. [CrossRef]

Duliniec, Aleksandra. 2001. Struktura i Koszt Kapitału w Przedsiębiorstwie. Warszawa: Wydawnictwo Naukowe PWN.

Duliniec, Aleksandra. 2007. Finansowanie Przedsiębiorstwa. Warszawa: PWE. 
Dulinec, Aleksandra. 2015. Wybór źródeł finansowania a optymalna struktura kapitału w przedsiębiorstwie. Zeszyty Naukowe Uniwersytetu Szczecińskiego. Finanse, Rynki Finansowe, Ubezpieczenia 74: 73-82. [CrossRef]

Duran, Mauricio M., and Sheryl-Ann Stephen. 2020. Internationalizoation and the capital structure of firms in emerging markets: Evidence from Latin America before and after the financial crisis. Research in International Business and Finance 54. [CrossRef]

Durand, David. 1952. Costs of Debt and Equity Funds for Business: Trends and Problems of Measurement. In Conference on Research in Business Finance. New York: National Beaureau of Economic Research, pp. 215-62.

Gajdka, Jerzy. 2002. Teorie Struktury Kapitału i Ich Aplikacja w Warunkach Polskich. Wydawnictwo Uniwersytetu Łódzkiego: Łódź.

Gajdka, Jerzy, and Marek Szymański. 2019. Changes in the Capital Structure of Polish Companies During the Last Twenty Years (1997-2017). Annales Universitatis Mariae Curie-Skłodowska Lublin-Polinia LIII 4: 53-68. [CrossRef]

Gan, Liu, Wujun Lv, and Yifei Chen. 2021. Capital structure adjustment speed over the business cycle. Finance Research Letters 39. [CrossRef]

Gostkowska-Drzewicka, Magdalena. 2014. Obligacje w strukturze kapitału przedsiębiorstw deweloperskich notowanych na GPW. Zeszyty Naukowe Uniwersytetu Szczecinskiego. Finanse, Rynki Finansowe, Ubezpieczenia 802: 94-95.

Guzanek, Arkadiusz, and Mariusz Trojak. 2012. Wpływ struktury kapitału na wartość rynkowa przedsiębiorstw notowanych na Giełdzie Papierów Wartościowych w Warszawie w latach 2005-2010. Studia Prawno-Ekonomiczne LXXXVI: 229-51.

Hand, John H., William P. Lloyd, and Robert B. Rogow. 1982. Agency Relationships in the Close Corporation. Financial Management 11: 25-30. [CrossRef]

Harris, Milton, and Artur Raviv. 1991. The Theory of Capital Structure. The Journal of Finance 46: 297-355. [CrossRef]

Haugen, Robert A., and Lemma W. Senbet. 1978. The Insignifance of Bankruptcy Costs to the Theory of Optimal Capital Structure. The Journal of Finance 33: 383-93. [CrossRef]

Jakubczyk, Beata, and Justyna Lewandowska. 2014. Teorie struktury kapitału w literaturze światowej. Journal of Finance and Financial Law 1: 65-81.

Janasz, Krzysztof. 2010. Kapitał w Finansowaniu Działalności Innowacyjnej Przedsiębiorstw w Polsce. Źródła i Modele. Warszawa: Difin.

Jaros, Jaroslav, and Viera Bartosova. 2015. To the capital structure choice: Miller and Modigliani model. Procedia Economics and Finance 26: 351-58. [CrossRef]

Jensen, Michael C., and William H. Meckling. 1976. Theory of Firm: Managerial Behavior, Agency Cost and Ownership Structure. Journal of Financial Economics 3: 305-60. [CrossRef]

Jerzemowska, Magdalena. 2018. Zadłużenie przedsiębiorstwa i jego analiza. In Analiza Ekonomiczna w Przedsiębiorstwie. Edited by Magdalena Jerzemowska. Warszawa: PWE, pp. 177-214.

Jonek-Kowalska, Izabela. 2020. Wartość przedsiębiorstw górniczych i jej determinanty. In Strategiczne i Operacyjne Zarzadzanie Przedsiębiorstwem Górnyczym w Kontekście Teoretycznych i Praktycznych Uwarunkowań Ekonomiczno-Finansowych. Edited by Izabela Jonek-Kowalska and Aneta Michalak. Warszawa: CeDeWu, pp. 91-105.

Kazemian, Soheil, and Zuraidah Mohd Sanusi. 2015. Earnings Management and Ownership Structure. Procedia Economics and Finance 31: 618-24. [CrossRef]

Kedzior, Marcin, Barbara Grabińska, Konrad Grabiński, and Dorota Kedzior. 2020. Capital Structure Choices in Technology Firms: Empirical Results from Polish Listed Companies. Journal of Risk and Financial Management 13: 221. [CrossRef]

Khémiri, Wafa, and Hédi Noubbigh. 2018. Determinants of capital structure: Evidence from sub-Saharan African firms. The Quarterly Review of Economics and Finance 70: 150-59. [CrossRef]

Kubiak, Jarosław. 2015. Wybór zewnętrznych źródeł kapitału w kontekście zmodyfikowanej teorii hierarchii. Zeszyty Naukowe Uniwesrystetu Szczecińskiego. Finanse, Rynki Finansowe, Ubezpieczenia 73: 685-95.

Michalak, Aneta. 2015a. Kapitałowe uwarunkowania zarządzania finansami przedsiębiorstwa górniczego na przykładzie polskich spółek węglowych. Zeszyty Naukowe Politechniki Ślaskiej. Organizacja i Zarządzanie 86: 337-47.

Michalak, Aneta. 2015b. Modele kosztu Kapitału i ich Implementacje w Zarzadzaniu Przedsiębiorstwem Górniczym. Warszawa: Difin.

Miglo, Anton. 2011. Trade-Off, Pecking Order, Signaling, and Market-Timing Models. In Capital Structure and Corporate Financing Decisions: Theory, Evidence, and Practice. Edited by Baker H. Kent and Gerald S. Martin. Hoboken: John Wiley and Sons, pp. 171-89.

Miglo, Anton. 2020. Zero-Debt Policy under Asymmetric Information, Flexibility and Free Cash Flow Considerations. Journal of Risk and Financial Management 13: 296. [CrossRef]

Miller, Merton H. 1977. Debt and Taxes. The Journal of Finance 32: 261-75. [CrossRef]

Modigliani, Franco. 1982. Debt, Dividend Policy, Taxes. Inflation and Market Valuation. The Journal of Finance 37: 255-73. [CrossRef]

Modigliani, Franco, and Merton H. Miller. 1958. The Cost of Capital, Corporation Finance and The Theory of Investment. The American Economic Review 48: 261-97.

Modigliani, Franco, and Merton H. Miller. 1963. Corporate Income Taxes and the Cost of Capital: A Correction. The American Economic Review 53: 433-43.

Mokhova, Natalia, and Marek Zinecker. 2014. Macroeconomic factors and corporate capital structure. Procedia-Social and Behavioral Sciences 110: 530-40. [CrossRef]

Mursalim, Mika Mallisa, and Hadri Kusuma. 2017. Capital Structure Determinants and Firms' Performance: Empirical Evidence from Thailand, Indonesia and Malaysia. Polish Journal of Management Studies 16: 154-64. [CrossRef]

Myers, Stewart C. 1977. Determinants of Corporate Borrowing. Journal of Financial Economics 5: 147-76. [CrossRef]

Myers, Stewart C. 1984. The Capital Structure Puzzle. The Journal of Finance 39: 575-92. [CrossRef] 
Myers, Stewart C. 2001. Capital Structure. The Journal of Economic Perspectives 15: 81-102. [CrossRef]

Nguyen, Thao, Min Bai, Yang Hou, and Manh-Chien Vu. 2021. Corporate governance and dynamics capital structure: Evidence from Vietnam. Global Finance Journal 48. [CrossRef]

Orlova, Svetlana, Joel T. Harper, and Li Sun. 2020. Determinants of capital structure complexity. Journal of Economis and Business 110. in press. [CrossRef]

Pacheco, Luis. 2016. Capital structure and internationalization: The cast of Portugese industrial SMEs. Research in International Business and Finance 38: 531-45. [CrossRef]

Pomykalska, Bożyna, and Przemysław Pomykalski. 2017. Analiza finansowa Przedsiębiorstwa. Wskaźniki i Decyzje w Zarządzaniu. Warszawa: Wydawnictwo Naukowe PWE.

Prędkiewicz, Katarzyna, and Paweł Prędkiewicz. 2014. Wybrane determinanty struktury kapitału mikro, małych i średnich przedsiębiorstw w Polsce. Zeszyty Naukowe Uniwersytetu Szczecińskiego, Finanse, Rynki Finansowe, Ubezpieczenia 65: 829-42.

Ripamonti, Alexandre. 2020. Financial institutions, asymmetric information and capital structure adjustments. The Quarterly Review of Economics and Finance 77: 75-83. [CrossRef]

Serghiescu, Laura, and Viorela-Ligia Văidean. 2014. Determinant Factors of the Capital Structure of a Firm-An Empirical Analysis. Procedia Economics and Finance 15: 1447-57. [CrossRef]

Shoaib, Adnan, and Muhammad Ayub Siddiqui. 2020. Earnings management and theoretical adjustment in capital structure performance pattern: Evidence from APTA economies. Borsa Istanbul Review. in press. [CrossRef]

Sierpińska, Maria, and Tomasz Jachna. 2007. Metody Podejmowania Decyzji Finansowych. Analiza Przykładów i Przypadków. Warszawa: Wydawnictwo Naukowe PWN.

Sierpińska, Maria, and Tomasz Jachna. 2017. Ocena Przedsiębiorstwa Według Standardów Światowych. Warszawa: Wydawnictwo Naukowe PWN.

Ullah, Atta, Chen Pinglu, Saif Ullah, Mubasher Zaman, and Shujahat Haider Hashimi. 2020. The nexus between capital structure, firm specific factors, macroeconomic factors and financial performance in the textile cestor of Pakistan. Heliyon 6. [CrossRef]

Vo, Minht T. 2021. Capital structure and cost of capital when prices affect real investments. Journal of Economics and Business 113. [CrossRef]

Włoszczowski, Beniamin. 2001. Kategoria alternatywnego kosztu kapitału w teorii zarządzania finansami. Zeszyty Naukowe Politechniki Łódzkiej. Organizacja i Zarządzanie 36: 71-79.

Yıldırım, Durmuş, and Ali Kemal Çelik. 2020. Testing the pecking order theory of capital structure: Evidence from Turkey using panel quantile regression approach. Borsa Istanbul Review in Press. [CrossRef] 